\title{
Some Morphological Aspects of Cylicocyclus brevicapsulatus (Nematoda: Cyathostominae) Parasite of Horse
}

\author{
Helio MA Costa†, Amalia VM Silva, Marcos P Guimarães*/+ \\ União Educacional do Vale do Aço, Ipatinga, MG Brasil *Departamento de Parasitologia, ICB, Universidade Federal de Minas \\ Gerais, Av. Antonio Carlos 6627, 31270-901 Belo Horizonte, MG Brasil
}

This paper describes some morphological aspects of Cylicocyclus brevicapsulatus (Ihle, 1920) (Nematoda: Cyathostominae) from Equus caballus in Brazil. The worms were studied using an optical microscope (measurements and illustrations) and a scanning electron microscope for a more detailed examination of the external morphology. The buccal capsule is very short, with a very thin wall, and the dorsal gutter is absent. Other morphological aspects are described including measurement of the spicules and gubernaculum.

Key words: Cylicocyclus brevicapsulatus - horses - morphology - scanning electron microscopy

Approximately 14 species have been described for the genus Cylicocyclus, some of which are difficult to identify because their original descriptions were incomplete. Lichtenfels et al. (1997) suggested a key with characters for the microscopical identification of $C$. nassatus and $C$. ashworthi. Kharchenko et al. (1997) and Lichtenfels et al. (1998) have redescribed some of the other species, but the only study carried out on C. brevicapsulatus since it was first described by Ihle in 1920 (as Cylicostomum brevicapsulatus) was by Skrjabin and Ershov (1933), Foster and Ortiz (1937), Lanfredi and Honer (1984) and SoutoMaior et al. (1999). Here we describe some morphological aspects of the species in order to facilitate its identification

Sixteen males and eight females were studied under an optical microscope. The specimens were cleared in phenol-alcohol ( 80 parts of phenol, 20 parts of absolute alcohol). Six male and six female specimens were identified and processed for the examination under scanning electron microscope (SEM) (Guimaraes \& Caldeira 1997).

Morphometric study

\section{Cylicocyclus brevicapsulatus (Ihle, 1920) Ershov, 1943 (Figs 1-14)}

The general characteristics are the same as those for the genus, but the hoop-like thickening of the posterior margin of the buccal capsule is more difficult to observe. The mouth collar is poorly developed. Lateral papillae are prominent above the mouth-collar. Submedian papillae have spindle-shaped tips extending above the mouth collar to the level of external leaf-crown (Figs 1,2). The external leaf-crown has 42-44 elements (Figs 7, 8) measuring approximately $2.5 \mu \mathrm{m}$ at the base, recurved outwards at the middle, and becoming pointed at the tip. The internal leaf-

\footnotetext{
Deceased in January 1999.

${ }^{+}$Corresponding author. Fax:+55-31-3499.2970. E-mail: pezzi@icb.ufmg.br Received 22 February 2001

Acceptd 23 August 2001
}

crown has approximately 64 small elements measuring approximately $3.65 \times 2.67 \mu \mathrm{m}$. The buccal cavity is very short, and nearly 9-10 times wider than it is deep. The walls of the buccal capsule are poorly developed. The dorsal gutter is absent. The esophagus is club-shaped. The cervical papillae (Fig. 9) lie posterior to the nerve ring, near the terminal end of the esophagus.

Males: measurements are shown in the Table. The dorsal lobe of the copulatory bursa is short and not separated, although the dorsal system is distinct. The middle dorsal ray is split from the base of externodorsal rays. Each of the middle branches has two auxiliary branches. The posterior auxiliary and middle branches have small offshoots (Fig. 5). The base of the lateral rays is a common stem (Fig. 3). The ventral system, with ventro-ventral and ventro-lateral rays, is not separated. The margin of the bursa is serrated, and has cilium-like formations (Fig. 10). Genital cone (Fig. 11), presenting on each side of the ventral surface, one appendage from which three or more papilla-like projections originate. Spicules thin, long, few sclerotised, fused in the final third and with an anchor-like tip with two bi-divided flukes (Fig. 12). Gubernaculum compact, with manubrium (Fig. 6).

Females: measurements are in the Table. The posterior end of the female is relatively broad, without lateral prominences. The tail is a little shorter than the vulva-to-anus distance (Fig. 4), cone like, and recurved dorsally (Figs 4, 13). Vulva simple (Fig. 14). Vagina is relatively short, vestibule large and bulky, sphincters and infundibula shorter than vestibule.

Taxonomic summary

Synonyms: Cylicostomum brevicapsulatum Ihle, 1920

C. (Cylicodontophorus) brevicapsulatum Ihle, 1922

Cylicobrachytus brevicapsulatus (Ihle, 1920) Cram, 1924

Trichonema brevicapsulatus (Ihle, 1920) Mönnig, 1926

Host: Equus caballus

Location in host: colon and caecum

Origin: State of Goiás, Brazil

The specimens (males and females) studied are shorter than those described by Ihle (1920) and Skrjabin and Ershov (1933). Measurements of height and width of the buccal cavity are very important in identifying the species, and 
our data are similar to those of Ihle (1920) and Skrjabin and Ershov (1933). Although the most distinctive characteristic of $C$. brevicapsulatus is the buccal cavity (morphology and measurements), additional characters are presented in the microscopical identification of the species, as was used by Lichtenfels et al. (1997) for $C$. nassatus and $C$. ashworthi. Measurements of vagina in Ihle (1920) and Skrjabin and Ershov (1933) are equivalent to the measurements of vagina and vestibule of females we studied.

\section{REFERENCES}

Foster AO, Ortiz PO 1937. A further report on the parasites of a selected group of equines in Panama. J Parasitol 23: 360364.

Guimarães MP, Caldeira MCM 1997. Scanning electron microscopy of Haemonchus similis (Nematoda: Trichostrongylidae) parasite of cattle. Rev Bras Parasitol Vet 6: 139-141.

Ihle JEW 1920. Cylicostomum brevicapsulatus $\mathrm{n}$. sp. eine neue Strongylide due dem Darm des Pferdes. Zentbl Bakteriol I

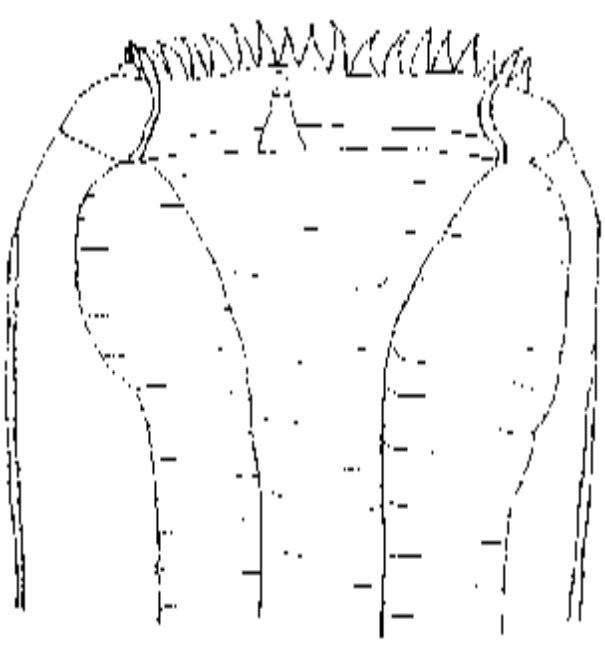

1
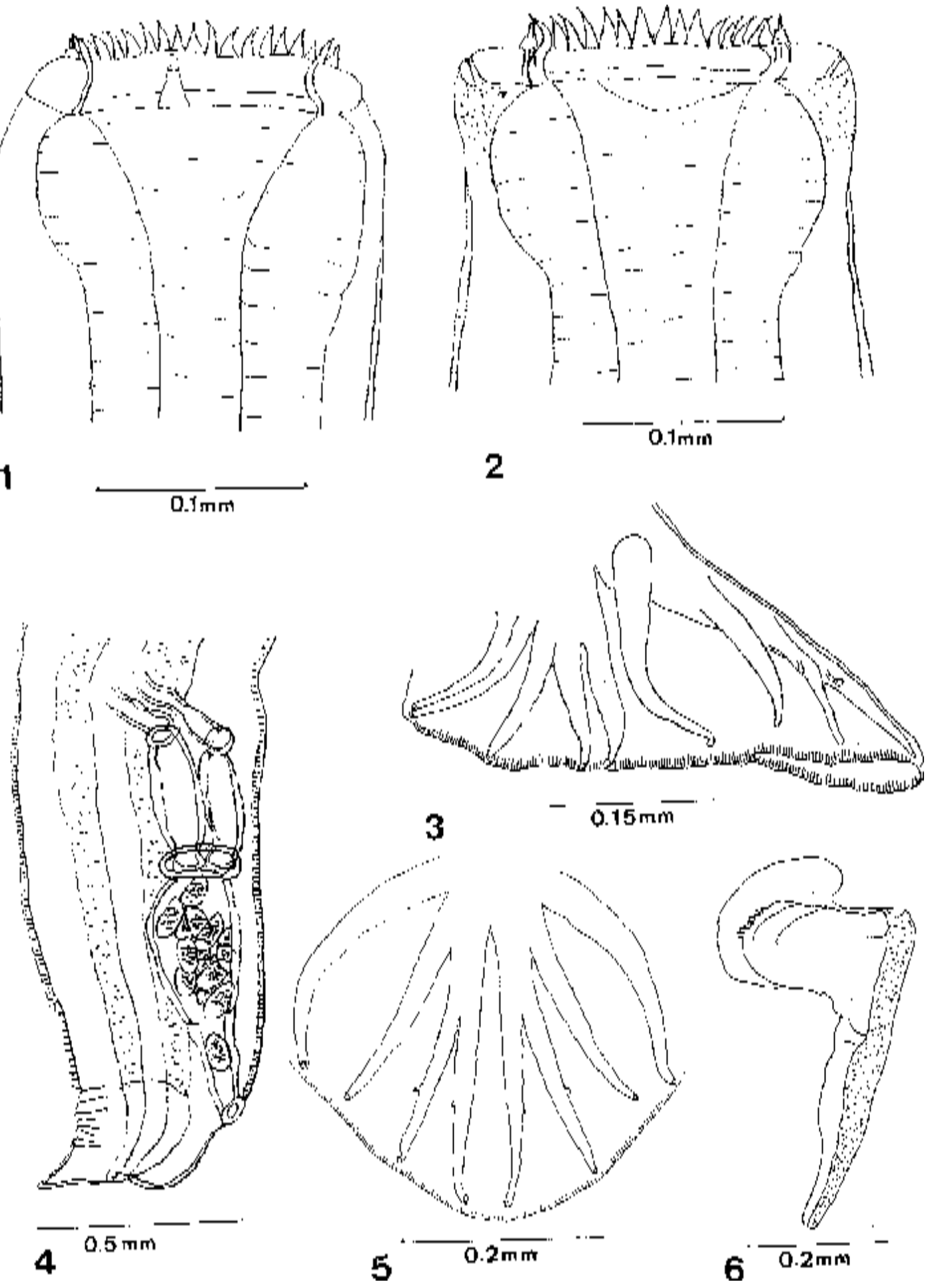

2

Cylicocyclus brevicapsulatus (Ihle, 1920). Figs 1 and 2: anterior region: dorso-ventral and lateral views. Fig. 3: lateral view of the bursa. Fig. 4: female tail, lateral view. Fig. 5: middle dorsal rays. Fig. 6: gubernaculum 

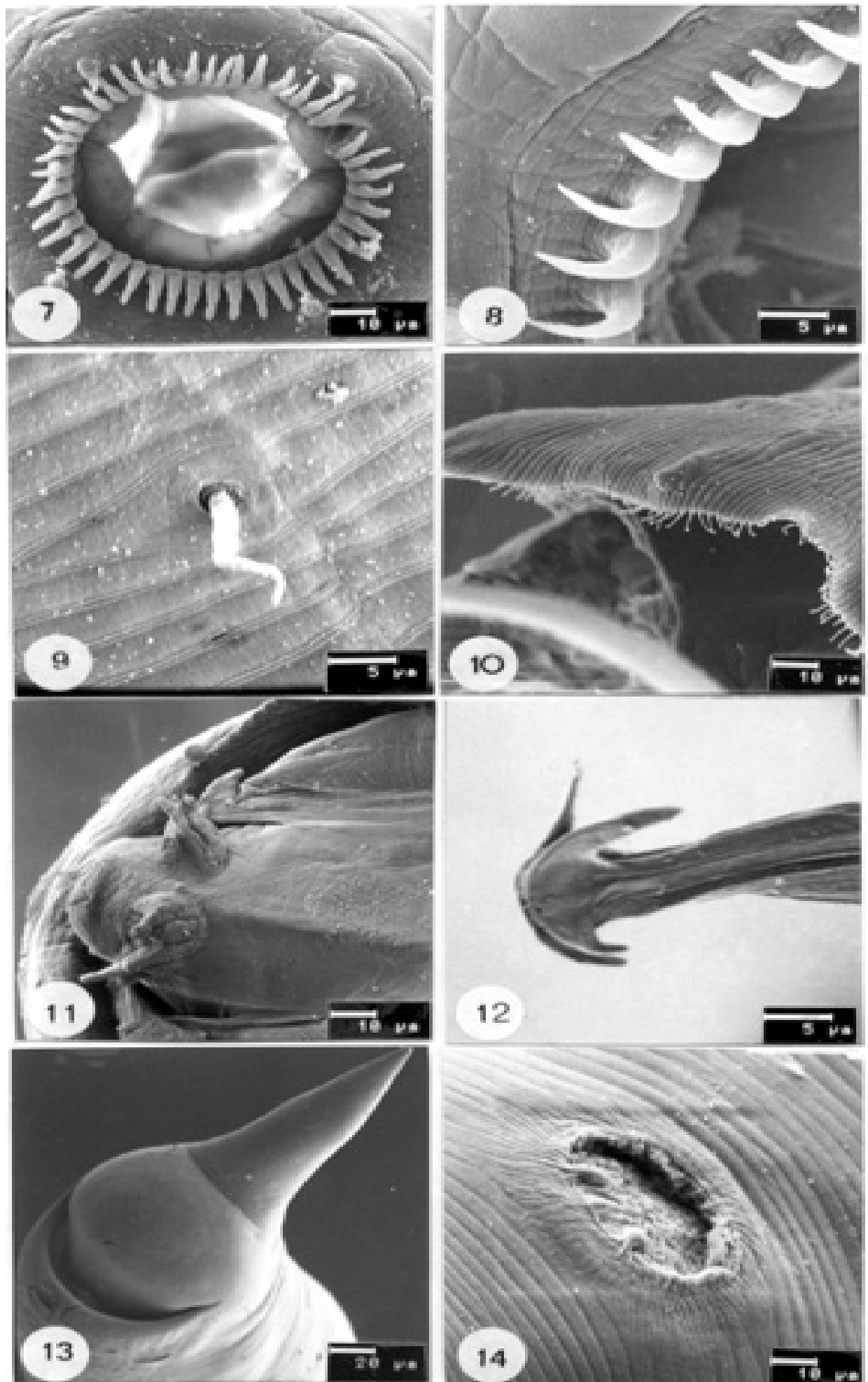

Cylicocyclus brevicapsulatus (Ihle, 1920). Observations under scanning electron microscope. Fig. 7: external leaf-crown. Fig. 8: external leaf-crown (details of elements). Fig. 9: cervical papilla. Fig. 10: margin of the bursa with cilium-like formations. Fig. 11: ventral surface of the genital cone with appendage and papilla-like formations. Fig. 12: spicules fused in the final third and with anchor-like tip (two bidivided flukes). Fig. 13: posterior end of the female. Fig.14: vulvar opening 
TABLE

Cylicocyclus brevicapsulatus - Morphometrics (mean, range and standard deviations) of males and females

\begin{tabular}{|c|c|c|c|c|c|c|}
\hline & \multicolumn{3}{|c|}{ Males } & \multicolumn{3}{|c|}{ Female } \\
\hline & Mean $(\mathrm{mm})$ & Range & $\mathrm{s}$ & Mean $(\mathrm{mm})$ & Range & $\mathrm{s}$ \\
\hline Body length & 6.99 & $5.29-7.90$ & 0.65 & 10.23 & $9.23-10.85$ & 0.55 \\
\hline Diameter at widest part & 0.52 & $0.42-0.62$ & 0.065 & 0.75 & $0.64-0.79$ & 0.067 \\
\hline Esophagus length & 0.467 & $0.434-0.499$ & 0.018 & 0.583 & $0.559-0.608$ & 0.018 \\
\hline Esophagus diameter ${ }^{a}$ & 0.164 & $0.127-0.189$ & 0.016 & 0.238 & $0.222-0.244$ & 0.008 \\
\hline Nerve ring $b$ & 0.242 & $0.217-0.255$ & 0.009 & 0.283 & $0.255-0.309$ & 0.017 \\
\hline Excretory pore ${ }^{b}$ & 0.385 & $0.341-0.434$ & 0.024 & 0.471 & $0.417-0.542$ & 0.038 \\
\hline Cervical papillae $^{b}$ & 0.389 & $0.353-0.412$ & 0.019 & 0.504 & $0.466-0.690$ & 0.036 \\
\hline Mouth collar height & 0.017 & $0.013-0.021$ & 0.003 & 0.021 & $0.017-0.025$ & 0.004 \\
\hline Mouth collar width & 0.131 & $0.120-0.163$ & 0.011 & 0.170 & $0.146-0.189$ & 0.015 \\
\hline Buccal capsule depth & 0.012 & $0.009-0.015$ & 0.002 & 0.015 & $0.013-0.017$ & 0.002 \\
\hline Buccal capsule width & 0.099 & $0.081-0.129$ & 0.018 & 0.124 & $0.106-0.139$ & 0.010 \\
\hline Submedian papillae & 0.010 & $0.008-0.012$ & 0.001 & 0.011 & $0.009-0.011$ & 0.001 \\
\hline External leaf crown & 0.027 & $0.021-0.038$ & 0.005 & 0.033 & $0.027-0.037$ & 0.004 \\
\hline Spicules length & 1.861 & $1.736-1.969$ & 0.068 & - & - & - \\
\hline Gubernaculum length & 0.242 & $0.211-0.271$ & 0.020 & - & - & - \\
\hline Vulva to anus distance & - & - & - & 0.285 & $0.229-0.336$ & 0.037 \\
\hline Tail length & - & - & - & 0.271 & $0.228-0.314$ & 0.034 \\
\hline Vagina & - & - & - & 0.271 & $0.212-0.358$ & 0.048 \\
\hline Vestibule & - & - & - & 0.515 & $0.429-0.602$ & 0.068 \\
\hline Sphincter & - & - & - & 0.386 & $0.325-0.533$ & 0.068 \\
\hline Infundibula & - & - & - & 0.368 & $0.326-0.407$ & - \\
\hline
\end{tabular}

$a$ : in the last third; $b$ : measurements from the anterior end

Abt Orig Bd 84: 562-565.

Kharchenko VA, Dvojnos GM, Krecek RC, Lichtenfels JR 1997. A redescription of Cylicocyclus triramosus (Nematoda: Strongyloidea): a parasite of the zebra, Equus burchelli antiquorum. J Parasitol 8: 922-926.

Lanfredi RM, Honer MR 1984. Uma nova chave para identificação simplificada das espécies da sub-família Cyathostominae (Strongylidae-Nematoda) parasito de Equus caballus no Brasil. Pesq Vet Bras 4: 67-72.

Lichtenfels JR, Kharchenko VA, Sommer C, Ito M 1997. Key characters for the microscocopical identification of Cylicocyclus nassatus and Cylicocyclus ashworthi (Nematoda: Cyathostominae) of the horse, Equus caballus. Proc Helminthol Soc Wash 64: 120-127.
Lichtenfels JR, Plit PA, Dvojnos GM, Kharchenko VA, Krecek RC 1998. A redescription of Cylicocyclus radiatus (Nematoda: Cyathostominae), a parasite of the ass, Equus asinus, and horse, Equus caballus. J Helminthol 65: 56-61.

Skrjabin KI, Ershov VS 1933. Gel'mintozy loshadei (horse helminthiases). Moskva-Leningrad, Sel'khozgiz, 408 pp. "apud" Popova (1965). Strongyloids of Animals and Man, Trichonematidae, Israel Program for Scientific Translations, Jerusalem, p. 41-63.

Souto-Maior MP, Rodrigues MLA, Anjos DHS, Andrade AA 1999. Estrutura das infracomunidades de nematóides estrongilídeos (Nematoda: Strongylidae) do ceco de Equus caballus naturalmente infectados proveniente da Região Metropolitana do Rio de Janeiro. Parasitol al Dia 23: 24-32. 